\title{
Economics of Brazilian performing arts: financing and employment
}

\author{
Manoel Silvestre Friques ${ }^{*}$ and Brayan Luque
}

${ }^{*}$ Correspondence:

manoel.sousa@unirio.br

UNIRIO, Rio de Janeiro, Brazil

\begin{abstract}
The paper attempts to assess and analyze the economics of Brazilian contemporary theatre, focusing on financing and employment indicators. It was considered only the official data published by public institutions. The reason for it is as economic as cultural: although Brazilian theatre is at least 500 years old and is inseparable part of Brazilian culture, it has never been a subject of an in-depth economic analysis.
\end{abstract}

Keywords: Brazilian performing arts, Economics of theatre, Entertainment engineering, Cultural economics

\section{Review}

Brazilian performing arts is as old as its nation. This means that there are, at least, two ways of approaching its history. It is possible to consider, on the one hand, the traditional rituals that native Indigenous people, such as the Bororo and Kadiweu tribes, have practiced for more than 500 years. From this broad point of view, theatre and religion are intertwined in ceremonies that must help people to overcome the struggles of life and death. In all the diversity of rituals that celebrated events and milestones in Indian's trajectories, there lies the basic principle of theatre: the transformation of one person into another.

In a narrower perspective, Brazilian performing arts was born along with the Portuguese discovery in 1500. From this date on, theatre was used by the Catholic Church as a powerful tool of catechism of Indians and Africans. During the first decades of colonization, priests, like José de Anchieta (1534-1597), created some plays that were usually performed in Catholic festivities. Frequently written in three different languages (Portuguese, Spanish and Tupi), these plays staged the main Bible's episodes in order to pacify Indian and African audience, showing them how to act and behave under the intense cultural imperialism of the colonial period.

It was not until the transfer of the Portuguese Court to Brazil that a formalized theatre has been established in the country. Escaping from the invasion of Lisbon by Napoleonic forces, Braganza Royal Family and its court departed for the Portuguese colony of Brazil in 1808. This "metropolitan reversal" that made Rio de Janeiro the capital of the Portuguese Kingdom and elevated Brazil to the same rank as Portugal, provided the basic structures for the development of the country's theatrical production. Theatre, then,

(c) 2016 The Author(s). This article is distributed under the terms of the Creative Commons Attribution 4.0 International License (http://creativecommons.org/licenses/by/4.0/), which permits unrestricted use, distribution, and reproduction in any medium, provided you give appropriate credit to the original author(s) and the source, provide a link to the Creative Commons license, and indicate if changes were made. 
became not a tool of catechism, but one important device of the Romantic civilizatory project.

Since then, performing arts have long played a vital and essential role in Brazilian culture. In the past two centuries, theatre directors, costume and light designers, dramatists, performers and other professionals created some of the country's masterpieces (Heliodora 2013). Many European genres were adapted to Brazilian colors, such as the comedy of manners, created originally by Molière, then developed by Martins Pena (1815-1848). Artur de Azevedo (1855-1908) actualized the Revue, a multi-act popular theatrical entertainment, in plays of grand impact and success among the audience. In 1943, Nelson Rodrigues, one of the best of Brazilian playwrights, settled the milestone of Brazilian Modern Theatre with "Vestido de Noiva" (Wedding Dress). Nowadays, contemporary production have flourished due to the work of distinguished theatre directors such as José Celso Martinez Correa, Amir Haddad, Antunes Filho, Aderbal Freire-Filho, Enrique Diaz, Felipe Hirsch, Bia Lessa, Gerald Thomas, Roberto Alvim, Georgette Fadel, among others.

Therefore, the cultural importance of Brazilian theatre is undeniable. Nevertheless, even from a broad or a narrow point of view of Brazilian theatre's history, there has never been published a single book focused on the economics of its production. Why did that happen?

One argument that justifies the lack of economical analyses on Brazilian theatre is what Ruth Towse call "facts for advocacy": "the, to an economist, curious belief that policy can be influenced by the presentation of facts about that for which support is sought. This belief [...] rests on the notion that 'size counts' - the bigger the item under investigation, the more it counts politically" (Towse 2000).

Following the basic assumptions of William Baumol's cost disease (Benhamou 2007), Brazilian theatre is not profitable. In contrast to the successful, long-running Broadway plays, most of the theatrical productions are subsidized by the government. Furthermore, they struggle to run theirs performances for more than 1 month. Folha de São Paulo's 2014 survey shows that the average running of plays in São Paulo-one of the most productive clusters of Brazilian theatre-is 38 days (Fig. 1).

Considering the "facts of advocacy", it is possible to say that Brazilian theatre doesn't count economically because its size doesn't count. But the fact that this artistic manifestation does not profit regularly means that its size is null, so does it not deserve any economic investigations? Brazilian theatre is invisible from an economic point of view because of its "cost diseases"? Or, is it imperceptible because nobody have never been interested in perceiving it?

The lack of information in the Performing Arts has made its economic perception often misunderstood. However, this field, as the whole cultural field, can present distinct and interesting features under the economic point of view. This paper attempts to assess and analyze the economics of Brazilian contemporary performing arts, focusing on financing and employment indicators. It aims to gather economic and cultural reports and to extract information related to performing arts, in order to collate their characteristics and evaluate its economic importance. The unavailability of such studies stimulated an interest in gathering data on the performing arts to help theatre policy-making in the future. Doing so, this article initiates to overcome the paradoxical situation: the 


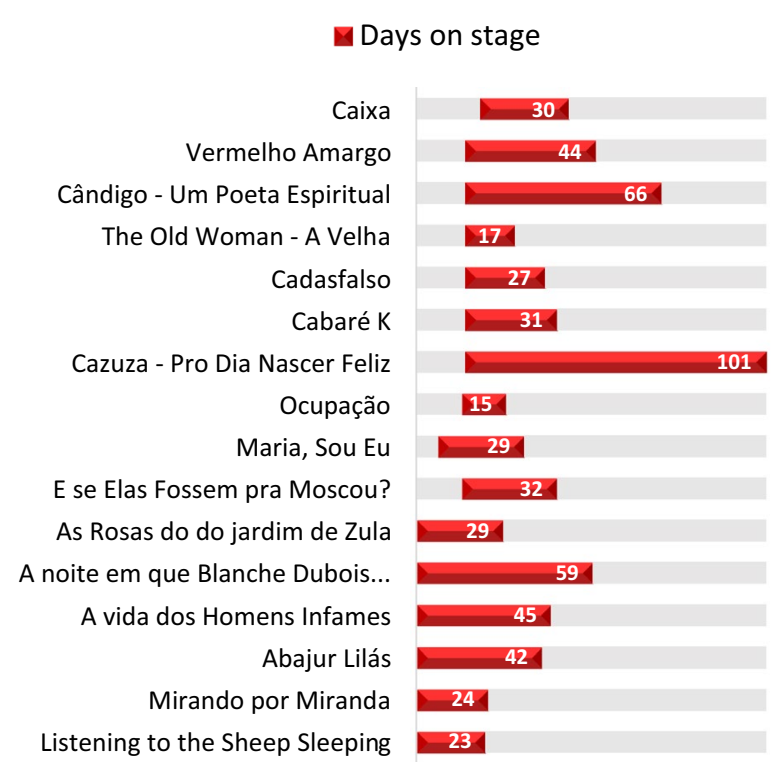

Fig. 1 Average running of plays in São Paulo between 2014 July and 2014 October. From: Folha de São Paulo

lack of information about Brazilian theatre economics on the verge of Information Economy (Castells 2006).

\section{Methods}

This paper ${ }^{1}$ adopted a quantitative, exploratory and descriptive methodology. Gathering official data published by public institutions, this analysis relies on secondary research.

The investigation of financing in Brazilian performing arts is based on the data available at the website of Ministry of Education (MinC). It covers all the cultural projects that applied for subsidies related to "Lei Rouanet", the most important Brazilian law that rules the sponsorship of artistic activities. As the most part of the theatrical production is subsidized, the data offers a coherent diagnosis of the sector. The information available refers to:

- Approved projects: cultural projects that have been approved by MinC. The approval does not mean that the project will occur. There is a second phase, in which the appliers should find a private institution that agrees to sponsor the activity;

- Accomplished projects: approved cultural projects that have been successful in finding a sponsor;

- Approved values: it refers to the amount of money for cultural activities approved by MinC. As in approved projects, the approved values are values that potentially can be used for cultural purposes;

- Gathered values: amount of money used to sponsor cultural activities;

- Sponsors: the biggest private institutions that, in a partnership with the government, financed cultural production.

\footnotetext{
${ }^{1}$ This paper was revised by Renan Laruan, to whom it is kindly dedicated.
} 
It must be said that this sector encompasses theatre, circus, dance, opera and other performing arts. The proposed method is primarily a statistical analysis of these indicators, concerning specifically the theatre sector, which responds to more than $70 \%$ of the projects in the Performing Arts sector. Furthermore, the analysis aims to show the Brazilian regional differences of the performance indicators.

Concerning the employment in theatre and performing arts, there have been used official reports from the institutions below:

- Applied Economic Research Institute (Instituto de Pesquisa Econômica AplicadaIpea): reports of Economics and Cultural Policy (2007).

- National Arts Foundation (FUNARTE): Yearbook of Cultural Statistics-Culture in Numbers (2009).

- Federation of Industries of Rio de Janeiro (FIRJAN): Creative Industries Mapping (2012).

- Brazilian Institute of Geography and Statistics: Cultural Indicators (2006 e 2010).

All records were gathered in data management software and spreadsheets. They are reconstructed in illustrated graphical models to facilitate the extraction of specific information and the analysis of new information crossings.

It must be said that this paper is one of the first outcomes of the research Supply Chain of Brazilian Theatre, developed within the course of Engineering at Universidade Federal do Estado do Rio de Janeiro (UNIRIO), the first Brazilian undergraduate program focused on cultural production.

\section{Results and discussions}

In the beginning of 1990s, Brazil was in the midst of a political and economic crisis. Predictably, the consequences also reverberated in the cultural sector, as demonstrated for instance in the extinction of Embrafilme, a Brazilian State funded company created in the sixties for production and distribution of national movies. Similarly, other cultural institutions were disbanded by the-sooner impeached-president Fernando Collor de Mello. For the most part of artists, these actions were a hard blow on Brazilian cultural production.

Meanwhile, the secretary of Culture, Sérgio Paulo Rouanet implemented the Law 8.313 (also known as Rouanet Law), which aims to promote cultural production through tax incentives. The law established the National Program to Support Culture (Pronac), which consisted of three mechanisms: the National Cultural Fund (FNC), the Cultural and Artistic Investment Fund (Ficart) and the incentive for cultural projects (patronage).

Since then, this law has become the most important mechanism to make feasible cultural production, which guarantees the Brazilian population the possibility to value its artistic manifestations. Earp et al. (2012) affirms that, between 1995 and 2011, while the Brazilian population and GDP grew by 25 and $62 \%$ respectively, the fund-raising through Rouanet law increased $3.500 \%$, as shown in Fig. 2.

The law, thus, encourages companies to make donations for cultural production in exchange for fiscal benefits, as well as visibility through sponsorship (which in Brazilian context is known as "Cultural Marketing"). Basically, it works like this: the government 


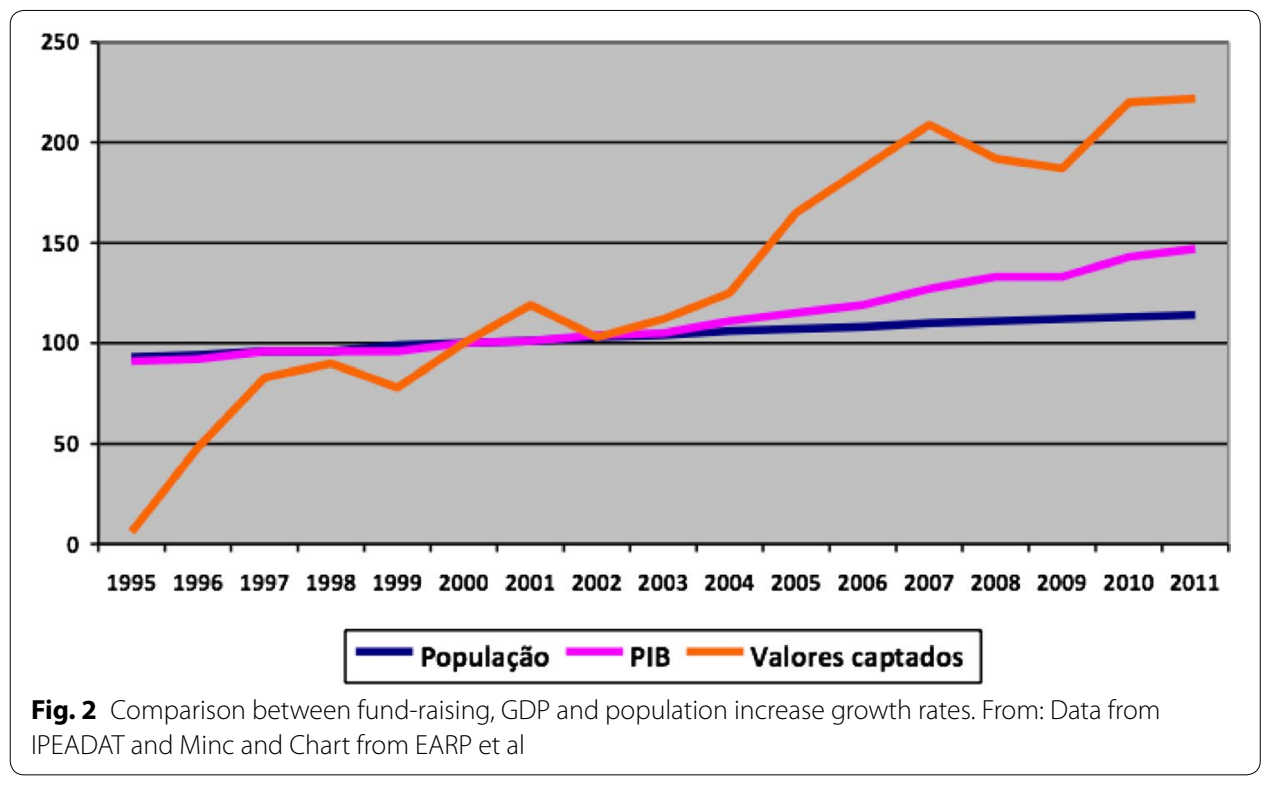

rules the two agents involved, the companies, on the one hand, and the cultural producers, on the other. If the private enterprises donate or sponsor projects that cover cultural activities, the government, in return, will grant deductions in their income taxes. There is a maximum deduction of less than $10 \%$ of the income tax. For this reason, the companies that most benefit from this law are conglomerates of banking (HSBC), industries, multinational companies (Petrobras), airlines (Gol, Avianca) and telecommunications sectors etc.

\section{The performing arts in Rouanet law}

Considering the interval between 1992 and 2014, the amount of money dispensed for the performing arts through Rouanet Law is shown on the Fig. 3.

Brazil is divided geopolitically in five regions: North Region (composed of the states: Roraima, Amapá, Pará, Amazonas, Acre, Tocantis and Rondônia), Northeast Region (composed of the states: Maranhão, Piauí, Ceará, Rio Grande do Norte, Paraíba, Pernambuco, Alagoas, Sergio and Bahia), South Region (composed of the states: Paraná, Santa Catarina and Rio Grande do Sul), Southeast Region (composed of the states: Minas Gerais, Espírito Santo, Rio de Janeiro and São Paulo) and Central-West Region (composed of the states: Mato Grosso, Mato Grosso do Sul, Goiás and Distrito Federal).

Taking into account this geopolitical division, there is an explicit concentration of approved projects in two regions: South and Southeast. While $11 \%$ of the approved projects come from the former region, $80 \%$ of the projects approved by Rouanet Law originate from the latter.

This concentration confirms partially the distribution of Brazilian population. Released by the Brazilian Institute of Geography and Statistics (IBGE), the most recent survey on the topic, informs that the estimatives for the population in 2014 were of 202.768 .562 people, distributed in the five regions, as follows: Central-West, 7,5 \%; North Region, $8,5 \%$; South, 14,3 \%; Northeast, 27,7 \%; and Southeast, 42 \% (Fig. 4). 


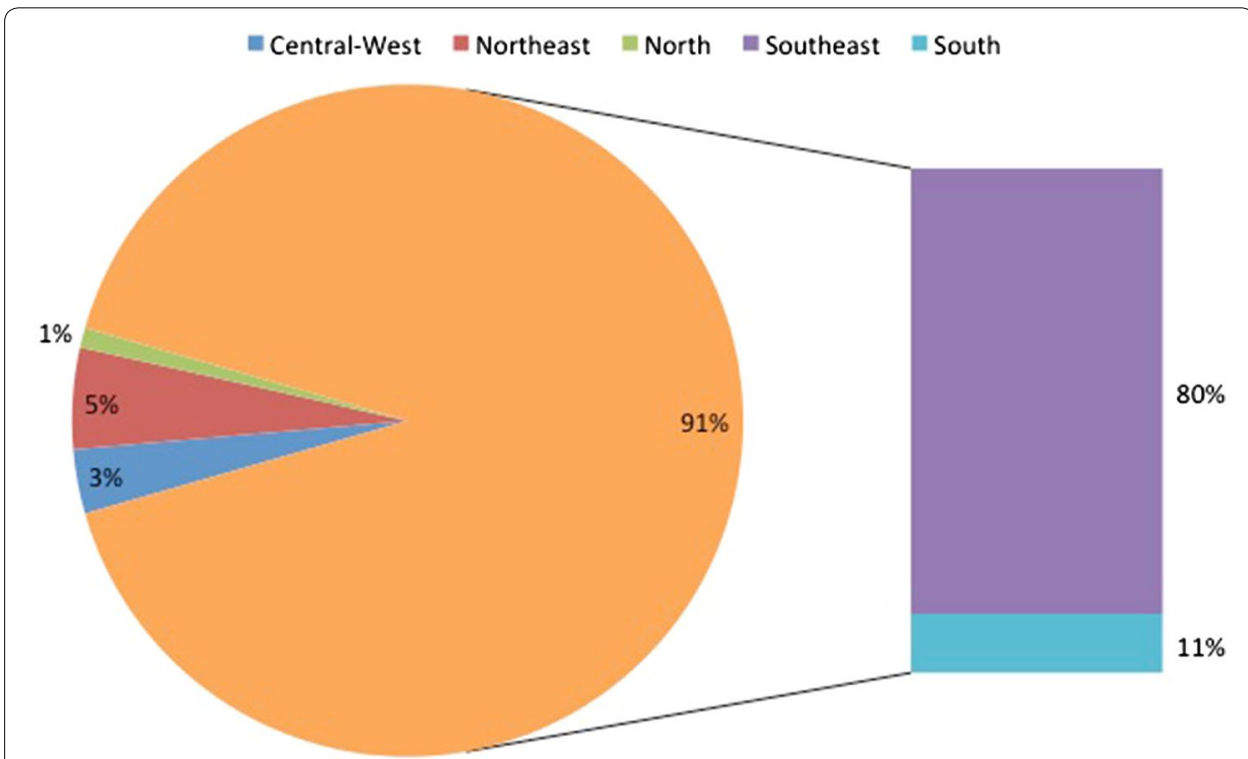

Fig. 3 Approved projects by Rouanet Law between 1992 and 2014, considering the five Brazilians regions defined by IBGE

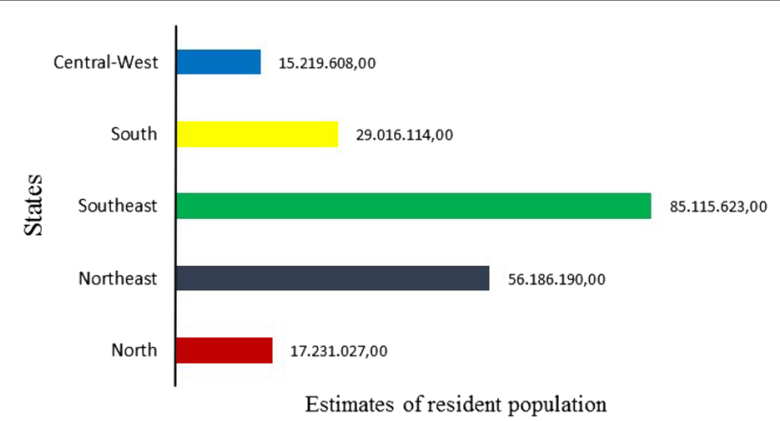

Fig. 4 Estimates of resident population in Brazil with reference date in 2014, July 1st. Source: http://www. ibge.gov.br

Both the population and cultural production are concentrated in the Southeast Region. But the demographic concentration is just half of the cultural clustering. Hence, this disparity does not explain one index by the other. If there is more cultural production in the Southeast due to its population, there is too much less concentration of population (42\%) than of cultural production (80\%).

The concentration of performing arts production is also observed in the analysis of the money collected between 1995 and 2013.

The Fig. 5 shows an increasingly disproportion between the money collected by the respective Brazilian regions. While the Southeast region already reached the amount of fifty millions of reais in 2000, the other regions only reached this value 12 years later. In 2012, the Southeast collected R $\$ 285.653 .66,200$, though.

Putting the Southeast Region aside, it is possible to look at the money collected by other regions (Fig. 6). 

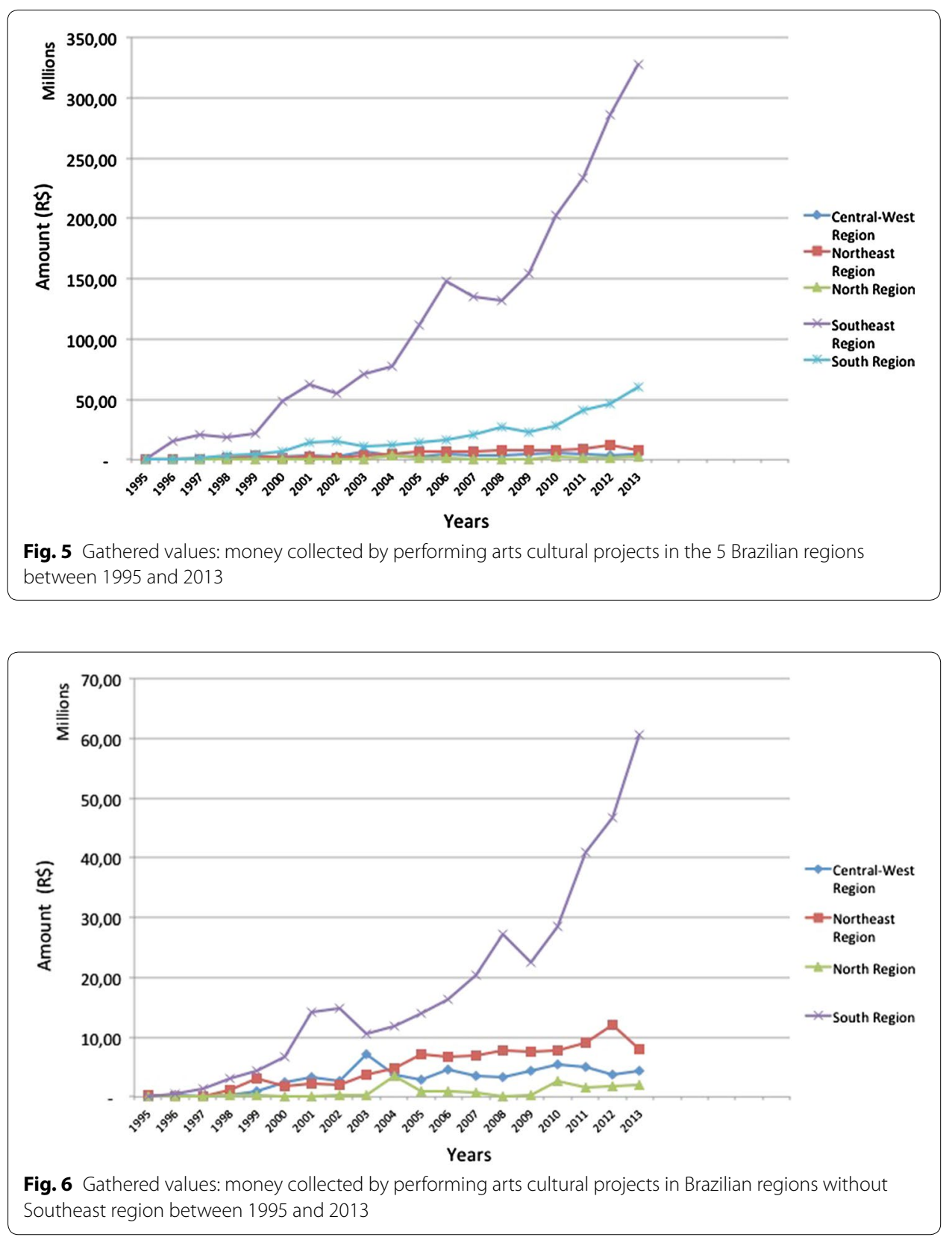

If the money collected by the four regions were close during the 90s, the values gathered by South Region increased much faster than the other regions after 2003. In 2013, this region had more than the double of the third region with more collected money (Northeast). Moreover, the Northeast, North and Central-West regions have similar performances, all of them with an annual gathered values under $\mathrm{R} \$ 10.00,000,000$ (the unique exception is for Northeast region in 2012).

The disparity between Southeast and other regions decreases effectively considering the relationship between the approved and the accomplished projects. From this angle, the efficacy of performing arts projects under Rouanet Law is low, between approximately $15 \%$ (for Central-West Region) and 25 \% (Southeast Region) (Fig. 7). 


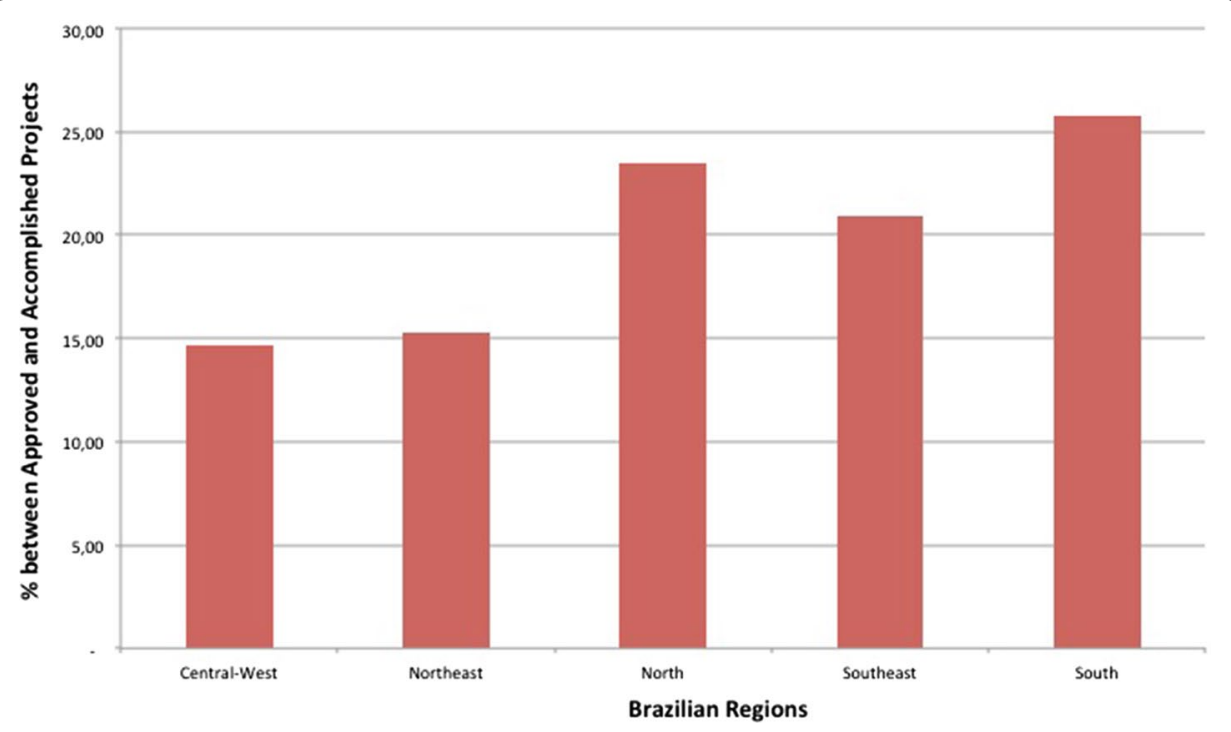

Fig. 7 Percentage of accomplished projects considering the total of projects approved by Rouanet Law between 1995 and 2013

If the Rouanet Law is the most important legal mechanism for sponsoring the performing arts, its average capacity does not reach even $20 \%$ for all the regions. It means that, from the universe of projects that applied for legal device, approximately $20 \%$ of them are really accomplished while the rest remains potential productions.

\section{Employment in Brazilian theatre}

Guiding the outlook for the following analysis, we will define the progress of the Performing Arts in the last years related to the job creation. The Table 1 shows the development of job creation in the cultural field in the last years.

The Table 1 shows that, until the year of 2001, the participation of the "Live performance and artistic activities" sector responded as just $5.20 \%$ of the total employment in the cultural sector. However, the same index represented just $4.05 \%$ in 1992, which demonstrates that the sector slowly gained representation in the cultural sector in the entire period.

Despite that, the job creation in the Performing Arts area scored the highest growing proportionally, if we consider all sectors. It has reached a significant growth of $68 \%$ between 1992 and 2001. As a comparison, the average growth of all cultural sectors together represented $23 \%$ in the same period. Furthermore, the second highest growing was in "Restricted Systems Information", with $58 \%$.

Table 2 contributes relevant information to the average income of the cultural labor market in the same period. The data below will serve as a basis to see if the increase in employment was accompanied by an increase in income.

The Table 2 shows that the sector in question does not have the same rhythm of growth and representativeness of job creation. In 2001, the average income of the sector was only $\mathrm{R} \$ 79,465$, one of the three worst average earnings in the cultural sector. Moreover, the growth variation was 16 \% between 1992 and 2001, much lower than the 
Table 1 Cultural labor market in Brazil between 1992 and 2001 Source Silva (2007)

\begin{tabular}{|c|c|c|c|c|c|c|c|c|}
\hline $\begin{array}{l}\text { Sector/ } \\
\text { year }\end{array}$ & 1992 & 1993 & 1995 & 1996 & 1997 & 1998 & 1999 & 2001 \\
\hline $\begin{array}{l}\text { 1. Mass } \\
\text { commu- } \\
\text { nication }\end{array}$ & 529,901 & 474,006 & 566,183 & 556,431 & 576,880 & 601,918 & 632,936 & 632,463 \\
\hline $\begin{array}{l}\text { 2. Restricted } \\
\text { systems } \\
\text { informa- } \\
\text { tion }\end{array}$ & 64,882 & 66,582 & 90,091 & 81,631 & 87,321 & 104,241 & 101,550 & 158,368 \\
\hline $\begin{array}{l}\text { 3. Arts and } \\
\text { high } \\
\text { culture }\end{array}$ & 317,528 & 330,965 & 351,944 & 307,185 & 335,773 & 332,165 & 327,578 & 388,972 \\
\hline $\begin{array}{l}\text { 4. Heritage } \\
\text { and } \\
\text { popular } \\
\text { culture }\end{array}$ & 349,028 & 361,715 & 332,030 & 314,295 & 270,673 & 288,949 & 327,332 & 395,483 \\
\hline $\begin{array}{l}\text { 5. Live per- } \\
\text { formance } \\
\text { and } \\
\text { artistic } \\
\text { activities }\end{array}$ & 135,227 & 139,351 & 154,377 & 175,492 & 184,642 & 213,406 & 202,459 & 226,766 \\
\hline $\begin{array}{l}\text { 6. Educa- } \\
\text { tion }\end{array}$ & $1,869,815$ & $1,981,072$ & $2,067,560$ & $2,090,889$ & $2,107,324$ & $2,228,535$ & $2,271,523$ & $2,430,232$ \\
\hline 7. Sports & 72,818 & 83,326 & 105,361 & 108,059 & 120,224 & 125,551 & 124,150 & 128,426 \\
\hline $\begin{array}{l}\text { Total } \\
\text { cultural } \\
\text { employ- } \\
\text { ment } \\
\text { market }\end{array}$ & $3,339,199$ & $3,437,017$ & $3,667,546$ & $3,633,982$ & $3,682,837$ & $3,894,765$ & $3,987,528$ & $4,360,710$ \\
\hline Grand total & $65,395,491$ & $66,569,757$ & $69,628,608$ & $68,040,206$ & $69,331,507$ & $69,963,113$ & $71,676,219$ & $75,458,172$ \\
\hline $\begin{array}{l}\text { Participa- } \\
\text { tion in the } \\
\text { cultural } \\
\text { market in } \\
\text { total }\end{array}$ & 5.1 & 5.2 & 5.3 & 5.3 & 5.3 & 5.6 & 5.6 & 5.8 \\
\hline $\begin{array}{l}\text { Participa- } \\
\text { tion of } \\
\text { culture } \\
\text { without } \\
\text { regard to } \\
\text { educa- } \\
\text { tion }\end{array}$ & 2.2 & 2.2 & 2.3 & 2.3 & 2.3 & 2.4 & 2.4 & 2.6 \\
\hline
\end{tabular}

$68 \%$ variation in the generation of employment. Not only the growth was low but it was also one of the smallest, if it is compared to other cultural sectors. Only the area of "Restricted Information Systems" was below, with a decrease in average income.

However, despite the average yield of live performance and artistic activities, which is less than the cultural average of $\mathrm{R} \$ 8195$, it is still higher than the average of overall employment in the country of $\mathrm{R} \$ 55,711$. It brings an earnings outlook for the cultural sectors above the national average.

\section{Work and time in the Brazilian performing arts}

The next analysis refers to compensation per hour worked. These data will serve as a comparison to understand the value of labor in relation to time spent. These data are detailed in Table 3. 
Table 2 Average income in the cultural labor market Source Silva (2007)

\begin{tabular}{|c|c|c|c|c|c|c|c|c|c|}
\hline Sector/year & 1992 & 1993 & 1995 & 1996 & 1997 & 1998 & 1999 & 2001 & Variation \\
\hline $\begin{array}{l}\text { 1. Mass com- } \\
\text { munication }\end{array}$ & 46,694 & 45,926 & 59,624 & 64,754 & 62,666 & 61,066 & 5877 & 56,591 & 1.21 \\
\hline $\begin{array}{l}\text { 2. Restricted } \\
\text { systems infor- } \\
\text { mation }\end{array}$ & $1.09,839$ & $1.07,816$ & $1.36,084$ & $1.21,858$ & $1.35,616$ & $1.27,243$ & $1.17,038$ & 9997 & 0.91 \\
\hline $\begin{array}{l}\text { 3. Arts and high } \\
\text { culture }\end{array}$ & 85,399 & $1.00,493$ & $1.30,407$ & $1.29,818$ & $1.38,704$ & $1.37,091$ & $1.31,573$ & $1.18,140$ & 1.38 \\
\hline $\begin{array}{l}\text { 4. Heritage } \\
\text { and popular } \\
\text { culture }\end{array}$ & 28,752 & 28,428 & 38,618 & 44,206 & 46,362 & 41,691 & 39,282 & 39,035 & 1.36 \\
\hline $\begin{array}{l}\text { 5. Live perfor- } \\
\text { mance and } \\
\text { artistic activi- } \\
\text { ties }\end{array}$ & 68,212 & 84,158 & $1.00,080$ & $1.04,442$ & 97,527 & 86,609 & 99,444 & 79,465 & 1.16 \\
\hline 6. Education & 57,312 & 60,568 & 77,376 & 81,818 & 84,549 & 92,351 & 87,499 & 88,817 & 1.55 \\
\hline 7. Sports & 60,047 & 70,223 & 93,864 & $1.09,018$ & 92,931 & $1.09,065$ & 91,554 & 83,663 & 1.39 \\
\hline $\begin{array}{l}\text { Total cultural } \\
\text { employment } \\
\text { market }\end{array}$ & 56,776 & 6107 & 78,952 & 82,687 & 853 & 88,675 & 84,047 & 8195 & 1.44 \\
\hline Grand total & 4094 & 44,516 & 57,478 & 5989 & 5928 & 59,022 & 54,604 & 55,711 & 1.36 \\
\hline
\end{tabular}

The hourly wage in the sector of live performance and artistic activities was $\mathrm{R} \$ 30.38$ per hour, the second largest in the cultural sector. Only the sector of arts and high culture, with R\$30.52 per hour, had a higher yield per hour, due to the appreciation given to this type of elite art. This relatively high pay compared to other sectors can be explained by two factors: appreciation and a few hours of work.

Two assumptions can be taken into account. On the one hand, the live activities have a greater appreciation, which can be translated as higher wages to employees. On the other hand, the same industry has a smaller workload than the others, because many do not work according to the Brazilian consolidation of labor laws (Consolidação das Leis do Trabalho, or simply CLT), the major legislation norm regularizing labor activities in the country. In the above calculation, as working hours is important in determining the index, if a sector has fewer hours worked, it represents a very high remuneration for time, even if the average monthly income does not mean extraordinary gains.

Table 3 Compensation per hour worked Source Silva (2007)

\begin{tabular}{ll}
\hline Area & Compensation per hour \\
\hline Heritage and popular culture & 10.41 \\
General labor market & 13.11 \\
Mass communication & 13.91 \\
Cultural labor market & 23.18 \\
Education & 26.24 \\
Restricted systems information & 29.18 \\
Sports & 30.03 \\
Live performance and artistic activities & 30.38 \\
Arts and high culture & 30.52 \\
\hline
\end{tabular}


Despite the speculations, it can be concluded that a high hourly earnings make workers being more devoted to the activities, because their earnings are valued. However, these gains can be illusory, since many do not work in the regime of $40 \mathrm{~h}$ per week. Therefore, working for a few hours is not satisfactory. This factor leads the worker to take more than one job to supplement their income.

The last IPEA data table shows relevant information concerning the average years of schooling for the cultural sector. These analyses will provide with information about the average time of schooling and evolution of educational time in this period.

The Table 4 shows that the sector of "Live performance and artistic activities" is the third worst sector regarding the average length of schooling between 1992 and 2001. It is not only that: the focused area also had an average schooling time $18 \%$ lower than the average of cultural sectors in 2001. However, this sector was the second with highest growth in study time, representing a growth of $15 \%$ in the period. Furthermore, the time of schooling is 43 and $37 \%$ greater than the average of non-cultural labor market and total labor market, respectively.

The above analysis is optimistic regarding the average time of schooling in the large sector of Performing Arts. Even though the average time of study is still inferior related to other sectors, its growth rate has been greater than the others. Besides that, it is a sector with a school time almost $50 \%$ higher than the non-cultural and general sectors.

In order to comprehend appropriately the relationship between schooling time and average earnings, a chart was generated comparing the cultural sectors by the classification of IPEA. This analysis allows to observe if the growth in schooling time was translated into major gains for workers, and if they are valued by the labor market, even if they did not have a great time of study.

The Fig. 8 shows that, over the years, the relationship between earnings and years of schooling increased in almost all cultural sectors. That is, there was an appreciation of their work. Regarding the analyzed sector, it has a growth curve until 1996 and a decrease between this year and 1998, year in which it had an instability. Despite the decrease between 1999 and 2001, the sector moved from the third position in 1992 to

Table 4 Average years of study between 1992 and 2001 Source Silva (2007)

\begin{tabular}{|c|c|c|c|c|c|c|c|c|c|}
\hline Sector/year & 1992 & 1993 & 1995 & 1996 & 1997 & 1998 & 1999 & 2001 & Variation \\
\hline 1. Mass communication & 7.58 & 7.82 & 7.95 & 8.19 & 8.08 & 8.57 & 8.73 & 8.97 & 1.18 \\
\hline 2. Restricted systems information & 12.06 & 11.93 & 12.06 & 11.85 & 11.59 & 11.65 & 12.09 & 11.68 & 0.97 \\
\hline 3. Arts and high culture & 9.71 & 10.13 & 10.51 & 10.28 & 10.75 & 10.91 & 10.96 & 11.09 & 1.14 \\
\hline 4. Heritage and popular culture & 5.03 & 5.19 & 5.69 & 5.88 & 6.14 & 6.08 & 6.06 & 6.82 & 1.36 \\
\hline 5. Live performance and artistic activities & 7.99 & 8.16 & 8.43 & 8.5 & 8.35 & 8.94 & 8.89 & 9.22 & 1.15 \\
\hline 6. Education & 12.07 & 12.02 & 12.14 & 12.25 & 12.39 & 12.5 & 12.53 & 12.76 & 1.06 \\
\hline 7. Sports & 11.62 & 11.42 & 11.07 & 11.95 & 11.69 & 11.79 & 12.15 & 11.39 & 0.98 \\
\hline $\begin{array}{l}\text { Average years of schooling in cultural } \\
\text { labor Market }\end{array}$ & 10.22 & 10.37 & 10.56 & 10.71 & 10.86 & 11.04 & 11.06 & 11.26 & 1.1 \\
\hline $\begin{array}{l}\text { Average years of schooling in non-cultural } \\
\text { labor market }\end{array}$ & 5.05 & 5.18 & 5.39 & 5.66 & 5.74 & 5.91 & 6.01 & 6.44 & 1.28 \\
\hline $\begin{array}{l}\text { Average years of schooling in total labor } \\
\text { market }\end{array}$ & 5.32 & 5.45 & 5.66 & 5.93 & 6.01 & 6.19 & 6.29 & 6.72 & 1.26 \\
\hline
\end{tabular}




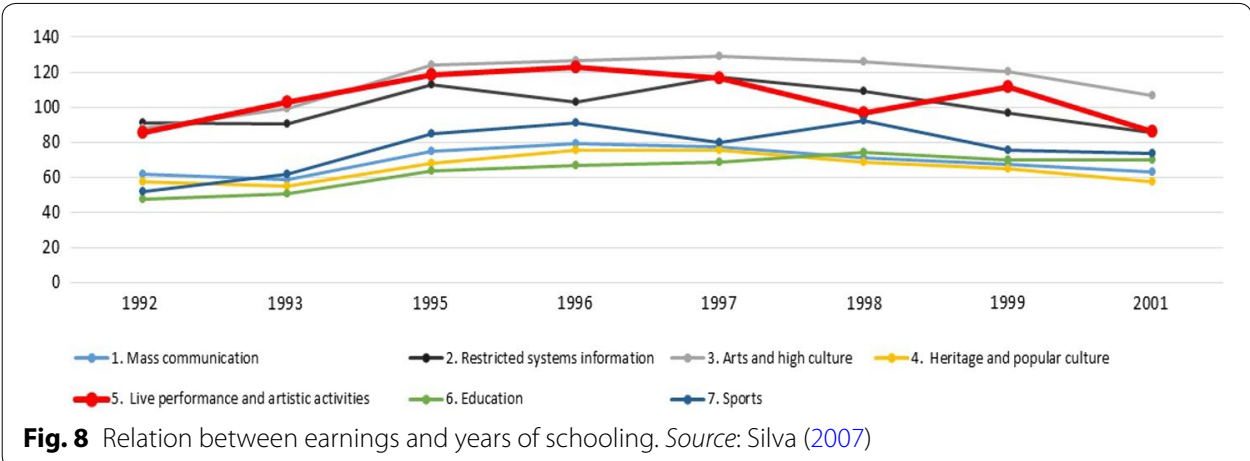

the second position in 2001. Although it was not a fast growing, the data show that, increasing the time of study in recent years is directly proportional to the increase in income. Then, the average yield increased.

This analysis could show, not that precisely, that the sector of Performing Arts has been valorized. In its period of growth, it was very close to being the most valued in relation to remuneration for study time.

Continuing the comparison with the other cultural sectors, the next chart analyzes the growth rate of participation of "Live performance and artistic activities" regarding the Performing Arts as a whole.

The Fig. 9 is an additional analysis made from Table 1. It proves that the representativity of the sector analyzed has increased over the years almost linearly. Even if the representation of $5.2 \%$ does not link the most of cultural jobs to the sector of the performing arts, the growth rate only reinforces our analysis that the industry has sustained growth and has gained representation in the cultural industry.

The following analysis is comparison between the employment rate in the sector of "Live performance and artistic activities" and GDP (Gross Domestic Product):

The Fig. 10 provides this investigation with important data to analyze the pro-cyclical industry dynamics of "Live Show and artistic activities". During the growth period of the economy, the cultural sector grew dramatically more than the share of GDP. There is a great elasticity of the sector indexes in relation to GDP: when GDP grows, the cultural

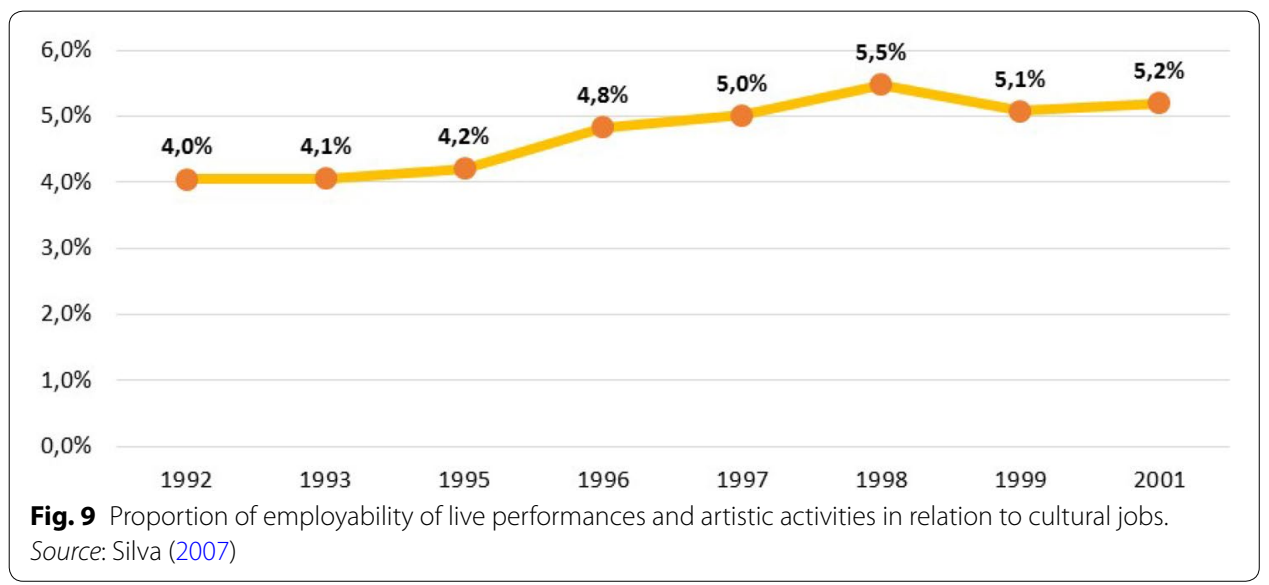




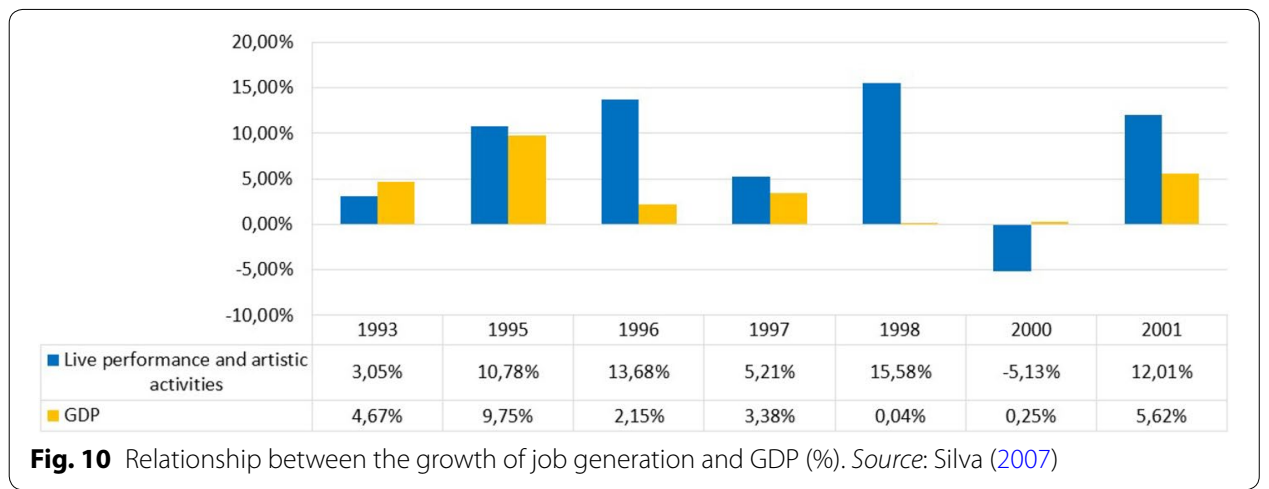

sector is growing further; when GDP shrinks, the cultural sector suffers the worst consequences.

Despite the apparent fragility, the artistic activity is not completely dependent on GDP and has a strong rating of growth. Thus, the sector encompassing the Performing Arts has achieved relative autonomy and can be considered one of the economic sectors with the highest growth in the period. These data verify the significant economic impact that the economy of the performing arts can potentially achieve in a future scenario.

The next graphs cross-reference data from FIRJAN and FUNARTE as a way to understand what sustains the industry's income growth in the respective Brazilian states. It will be possible to comprehend if an increase of Public or Private incentives can further leverage their growth. The following analysis is a comparison between the average earnings of the performing arts by state and the number of theatrical installations and related undergraduate courses.

The data from FIRJAN and FUNARTE does not cover the same year. Despite that, it is possible to analyze the relationship between the number of theaters and the average monthly earnings by states. The average monthly salary can create an illusory effect in some regions, due to the disparities between them. However, it is expected that, the greater number of theaters, greater will be the cultural activity in that location, even if does not reflect in a higher average income.

In the Fig. 11, on the main axis to the left, there is the number of theaters per state. On the secondary axis on the right, there are the average monthly earnings by states. The chart reveals that the relationship between the number of theaters and the average earnings for States is not fully proportional. Some states show different than expected results: Acre and Sao Paulo possess a similar performance, despite the difference in the number of theaters. Even though, there is a slight increase in average income from Rio Grande do Sul (RS) to São Paulo (SP), showing that, although not a rule, the availability of theaters is a key factor in the increase of income in the region, for the sole reason of having an appropriate workplace.

Even though many theatrical activities do not require a fixed location for presentation, the presence of theatre venues means that there is a wider range of staging possibilities. Moreover, even if the average income does not increase, there will be an increase in the number of jobs generated by the sector only by providing more performance spaces. 


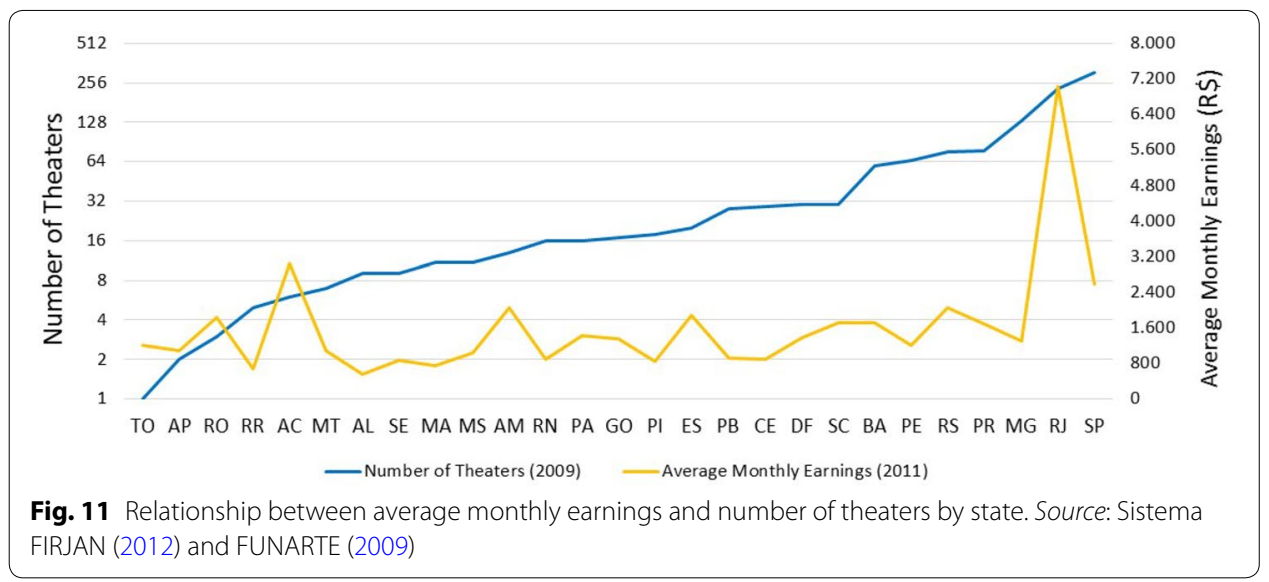

The next graph relates the average monthly income to the number of undergraduate courses.

The Fig. 12 provides the link between average earnings and undergraduate courses in each state. The relationship with the undergraduate programs took into consideration all related courses while they were both Theatre and Performing Arts.

Theoretically, we would consider that the greater the number of undergraduate courses, the higher the salary of those involved, as a state with a wider educational program would provide a large number of qualified employees, therefore, better paid. However, the table shows that the theoretical premises do not correspond with the observed data. Some States, although do not offer any degree course, have an average monthly income almost equal to others who have, in average, five. Therefore, the numerical analysis demystifies the idea that a greater amount of educational spaces would increase the average income of workers.

However, it is noteworthy that, as in the comparative number of theaters, the evolution of the employment rate cannot only be analyzed by the average monthly salary. Information such as the number of employees in the theatrical sector provides with a new insight, since the greater the supply of working in the theater area, possibly the greater the number of employees in the sector.

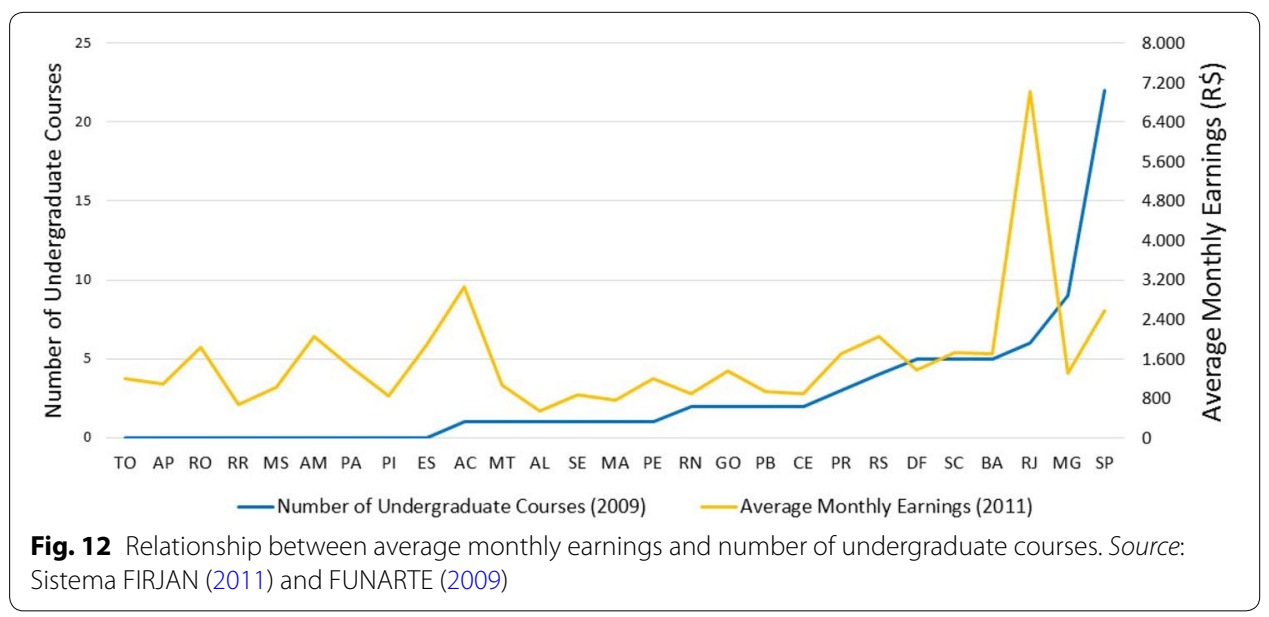


It is worth noting that two representative states of the Brazilian economy are in opposite situations on the above analysis: Rio de Janeiro and São Paulo. The former has six undergraduate courses and an average monthly income of R\$7.01,500-the country's largest. However, São Paulo, which has a total of twenty-two undergraduate courses, has an average income of $R \$ 2.58,100$. Then, it is lower than states like Acre, which has just one undergraduate degree. These outliers distort the analysis, which, on the other hand, may have some reasons for this discrepancy.

Rio de Janeiro has a consolidated theatrical industry and a huge association with the television industry (which often, in turn, offer more attractive wages). In accordance to FIRJAN's data (2009), the actors are professionals with the third largest wage gain of Creative Industry in Brazil, receiving an average amount of $\mathrm{R} \$ 10.34,800$.

São Paulo is more populous than Rio de Janeiro. For this reason, the larger is the sample data, more diluted will be the analysis if many professionals have income below average.

In other words, the State of São Paulo may contain a great amount of professionals with higher wage than Rio de Janeiro's and this may be the result of its offer of undergraduate courses for the qualification of its professionals. However, as the number of workers in the Performing Arts sector is much larger and many of them have lower earnings than the average, these data mean that the state, in general, have a low average monthly income.

\section{Conclusions}

Considering the financing indicators provided by Rouanet Law, the fund-raising increased $3.500 \%$ while the Brazilian population and GDP grew, respectively, 25 and $62 \%$ between 1995 and 2011. This great increase is associated, though, with a huge concentration of performing arts production in the Southeast Region. Moreover, from the universe of approved projects by the Law, approximately $20 \%$ of them are really accomplished while the rest remains potential productions. It means that Rouanet Law has a low efficiency rate.

Another problem associated with this legal mechanism is the distance between theatre production and its audience. Since each play begins its season with its all costs covered by the sponsors, the producers are not really worried about the empty seats in the audience. The artists can perform to chairs, then. This is one of the reasons for the even shorter running of Brazilian plays nowadays.

Concerning the employment in performing arts, the income of the theater sector has shown an average rate higher than the overall average of the country, bringing a positive perspective. Even slightly, there has been a recovery in the sector of the Performing Arts and, consequently, of Culture. Moreover, in the analyzed period of growth, the sector was very close to being the most valued in relation to compensation for study time.

Despite the apparent fragility, it is clear that artistic activity is not dependent on GDP and has a strong rating of growth. This information makes it a steadier sector, since it is not directly affected by the variations of this important economic indicator. The autonomy of growth of this industry is another important factor that makes it one of the economic sectors with the highest growth in the period. 
Thus, the cultural production driven by creative industry is a sector with enormous potential for formal employment generation. The growth can be optimized through investments and better monitoring of public officials to present growth rates and ever better return, positively influencing the economic results of the country.

Finally, it must be said that the analyses above are just the first steps towards the comprehension of the dynamics of Brazilian theatrical production.

Authors' contributions

MSF and BL made substantial contributions to the work reported in the manuscript. MSF was responsible for the conception, the design of study and the acquisition of data. BL and MSF carried out the analysis, the interpretation of data and the drafting of the manuscript. Both authors read and approved the final manuscript.

\section{Competing interests}

The authors declare that they have no competing interests.

Received: 21 June 2016 Accepted: 9 August 2016

Published online: 24 August 2016

\section{References}

Benhamou F (2007) A economia da cultura. Ateliê Editorial, Cotia

Castells M (2006) A sociedade em Rede: do conhecimento à política. In: Castells M, Cardoso, G (org) A sociedade em rede: do conhecimento à acção política. Imprensa Nacional - Casa da Moeda, Lisboa

Earp F, Kornis G, Joffe P (2012) A lei Rouanet às vésperas da maioridade. In: Annals of III international seminar on cultural policies. Fundação Casa de Rui Barbosa, Rio de Janeiro

FUNARTE (2009) Cultura em números: anuário de estatisticas culturais 2009. Minc, FUNARTE, Brasília

Heliodora B (2013) Caminhos do Teatro Ocidental. Perspectiva, São Paulo

Silva FA (2007) Economia e Política Cultural: acesso, emprego e financiamento. IPEA, Ministério da Cultura, Brasília

Towse R (2000) Cultural economics, copyright and the cultural industries. In: Quarterly Journal of Budapest University of Economic Sciences and Public Administration, volume XXII

Reports

Cultura em números: anuário de estatísticas culturais 2009. Minc, Brasília, 2009

IBGE (2006) Sistema de Informações e Indicadores Culturais

IBGE (2010) Sistema de Informações e Indicadores Culturais

Sistema FIRJAN (2011) Indústria Criativa, Mapeamento da Indústria Criativa no Brasil

Sistema FIRJAN (2012) Indústria Criativa, Mapeamento da Indústria Criativa no Brasil

\section{Websites}

http://www1.folha.uol.com.br/ilustrada/2014/07/1492336-tempo-de-duracao-das-pecas-em-cartaz-encolhe-nosteatros-de-sao-paulo.shtml

http://www1.folha.uol.com.br/ilustrada/2014/07/1492347-publico-diminui-nos-teatros-de-sao-paulo-e-sessoes-encolhem.shtml

\section{Submit your manuscript to a SpringerOpen ${ }^{\oplus}$ journal and benefit from:}

- Convenient online submission

- Rigorous peer review

- Immediate publication on acceptance

- Open access: articles freely available online

- High visibility within the field

Retaining the copyright to your article

Submit your next manuscript at $>$ springeropen.com 